Editorial Comment

\title{
二心室修復後の純型肺動脈閉鎖症：新たな課題
}

\begin{tabular}{|l} 
大場 淳一 \\
市立旭川病院胸部外科
\end{tabular}

\section{Our Research Agenda for Patients with Pulmonary Atresia with Intact Ventricular Septum after Biventricular Pepair}

Jun-ichi Oba

Department of Cardiovascular Surgery, Asahikawa City Hospital, Hokkaido, Japan

今月号の本誌には, 石丸らの論文 ${ }^{1)}$ が掲載されている. 純型肺動脈閉鎖症 (PAIVS)の二心室修復 (BVR) 後遠隔期 に magnetic resonance imaging (MRI) を用いて左右心室の収縮機能を調べたところ, 健康成人に比べて低值であった という要旨である.この論文から示唆される主な論点は以下の 3 点と考える.

(1)先天性心疾患における MRI の意義

(2)心室収縮力の指標としての最大収縮力

(3) PAIVS 遠隔期の問題.

本稿では上記 3 点の現況を述べ, 石丸論文から示唆される今後の課題について述べる.

\section{1. 先天性心疾患診療における MRI の意義}

かつては心室の形態や機能を評価する手段は心臓カテーテル検査, 心室造影検査が主流であった. やがて非侵 襲で繰り返し施行できる心臟超音波検査がそれにとって代わった. 左室の形態や容量, 収縮・拡張機能の評価は 心臓超音波検査でほぼカバーできる。一方, 先天性心疾患では左室のみならず右室の評価が重要であることは論 を待たない。

心臓超音波検査は右室の形態評価が弱点である. 先天性心疾患の右室はしばしば複雑な形態であり，心臓超音 波のみで, その全貌を明瞭に描出することは困難である。したがって右室の壁運動や収縮・拡張機能の評価は, 心 臓超音波検査が苦手とするところである。この点において MRI は心臟超音波検査よりも優れている ${ }^{2,3)}$.

CT でも形態と機能の評価は可能であるが, 放射線被曝の問題があること, しばしば造影剤が必要であること, 徐脈を誘導するためのベータブロッカー投与下では必ずしも正確な評価ができないこと, などが問題である.

MRI は非侵襲的で放射線被曝がなく造影剂が不要であることに加えて, 心筋と内膜, 血液とのコントラストが 良好であること, 肥満や肺気腫に影響されず，したがって症例間で画質のばらつきが少ないことが有利な点であ ろう. 複数の学会により策定された appropriateness criteria $\left.{ }^{4}\right)$ では, 複雑心奇形の形態と容量の評価に拈いて MRI は A (appropriate), score 9 となっている〔ちなみにこの criteria では機能の評価においてはU (uncertain), score 6 であっ た].いまや MRIが gold standard とさえ言われている5 .

一方 MRIにもさまざまな弱点がある。撮像に時間がかかること，したがって特に小児では鎮静が必要になる場 合があること, 高度な撮像技術が必要であること, 目的に応じた撮像法の標準化が十分ではないこと, 解析の際に 心内外膜のトレースが半自動であることから, 操作者個人の技術レベルの影響を受けやすいこと, 不整脈による 画質低下があることなどが指摘されている，新たに登場した 3 T の MRI は SN 比が改善され, 良質な画像が得られ ている.また 32 チャンネルコイルの MRIでは撮像時間が従来の約半分に短縮されるという ${ }^{6)}$. 今後は, 撮像法の 標準化, 解析の自動化, 呼吸・心電図同期などの工夫7)が課題となるだろう。 


\section{2. 収縮機能の指標としての maxPWR/EDV ${ }^{2}$}

「心機能」が包含する範囲は広い. 代表的なものは収縮機能と拡張機能である. 石丸論文では収縮機能に焦点を 当てて調べている.

Frank-Starling の法則が教えるところでは，単一心筋の仕事量は収縮前の心筋長に依存する。これを丸ごとの心 臓に応用すると「心蔵の仕事量は前負荷に依存する」と言い換えることができる。すなわち収縮機能はアプリオリ に負荷に依存する。

血圧, 駆出率, 心筋収縮率などの臨床的に簡便に測定ないし算出できる収縮機能の指標は, いずれも loaddependentである. 負荷に依存しない「純粋な」収縮機能指標としては, 圧容積曲線から求められる収縮期末圧容積 関係の勾配，すなわち Emax ないし $\mathrm{Ees}^{8,9)}$ が gold standard である ${ }^{10)}$. しかし, 心内腔にカテーテルを挿入すること が必須であり侵襲的である。技術的にも倫理的にも臨床に実用的とは言い難い. そのような背景から, Emax ない

し Eesに代わる収縮機能の指標が求められていた。

近年, 心筋最大収縮力 $\left(\operatorname{maxPWR} / \mathrm{EDV}^{2}\right)^{11)}$ が収縮機能指標として注目されてきた. 動物実験では Ees とよく相関 するとされ ${ }^{11,12)}$, 心臓超音波検査で求めることが可能なことからヒトでも応用された. 動物実験と同様の良好な相 関が得られている

石丸論文では MRI を用いて両心室の maxPWR/EDV 2 を算出している. 収縮機能の指標，しかも右室のそれを MRI で非侵襲的に算出できる可能性を示した点が新しい. しかし一方では解決すべき課題があり，それはすなわ ち今後の研究の方向性を示唆しているので, この点について言及しておきたい.

まず第一点は, 右室の maxPWR/EDV ${ }^{2}$ の validation が現時点では十分とは言い難い点である. 前述のように動物 実験やヒ卜臨床での左室の maxPWR/EDV は, ある程度 validate されている. 右室の maxPWR/EDV ${ }^{2}$ は Ees と相関

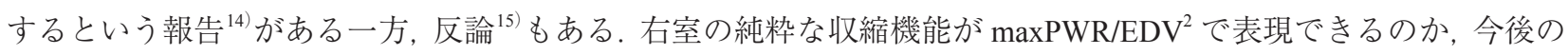
研究課題の一つであろう ${ }^{16)}$.

第二点は, MRI で測定算出した maxPWR/EDV 2 の, validation がなされていない点である. 石丸論文では MRIで 算出できる可能性を示しているが, 著者の知る限りでは過去にこのような報告はない，その意味では新しい試み であり, 今後の研究で評価されるべきものである. 前述のように MRIの撮像技術, シーケンス, プログラムは急速 に進歩している. 石丸論文は急速に進歩しつつある MRI の恩恵を受けたものであるが, その一方で急速に進歩し つつあるがゆえに撮像条件に標準化されたものがなく，解析がいまだ半自動である(したがって操作者の影響を受 ける)などの制約がある. 石丸論文では詳述されていないが, 今後の研究の進展のためには, MRIの撮像条件を記 載して比較することが重要であろう，同時に動物実験や臨床的に利用可能な他のモダリティ(例えば心臓カテーテ ル検査, 心臓超音波検査) との対比によって, 妥当性を validateすることが必要である。

\section{3. 純型肺動脈閉鎖症の遠隔期成績}

PAIVS は稀な疾患であるが生命予後が不良で, 治療戦略は長らく議論されてきた。現在では, 山岸17), 矢崎 ${ }^{18)} の$ 優れた教育的総説にみるように, 形態を把握, 評価することによって採用すべき戦略がほぼ確立されており, そ の短期的な成績も安定している。すなわち右室が tripartite か否か, 三尖弁輪径や右室容量から予想される右室の 発育度, 冠循環などの「形態」によって, 一心室修復に向かうのか BVRに向かうのかがほぼ決断できる. Simple strategy から balanced approach にシフトすることによって先天性心疾患の中では最劇的な治療成績の改善をみた 疾患の一つとなった ${ }^{19)}$.

治療成績の改善, 安定とともに必然的に長期生存例も増えてくる。一心室修復や BVR の長期遠隔期の成績が議 論され始めたのは, 比較的最近のことである20). 遠隔期でのいくつかの問題点が観察されている ${ }^{21)}$.

形態的にはBVRのよい適応であった症例でも, BVR 後遠隔には不整脈, 右室の拡大, 運動耐用能の低下が指摘

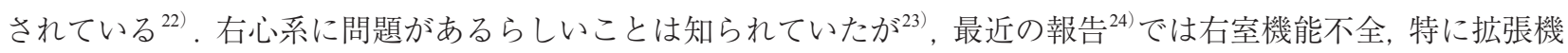
能の異常に原因を求める論文がある.さらに右室の発育可能性, 肺循環への寄与度を事前に予測できないことが 問題との指摘25)がある.

前述のと抢り, 右室はその全体を把握することが困難であったが, MRI の登場によって形態把握は容易になっ た.さらに delayed enhance によって心筋の性状も把握が可能になった. ファロー四徴症 ${ }^{26)}$ やフォンタン手術後 ${ }^{27}$ 遠 隔期での心機能低下と心筋線維化との関連はすでに指摘されていたが, PAIVS でも同様の結果を示唆する論文 ${ }^{28)}$ 
もある。これらの成果もまたMRIの急速な進歩の恩恵といえる.

MRI という新しいモダリティを応用することによって, 形態のみならず機能も把握できるようになった現在, PAIVS の臨床研究の方向性を以下のように推測している. 遠隔期に至った症例の詳細な形態的機能的評価を進 めること, 新たなモダリティを治療前の症例にも応用して形態と機能を把握すること, 結果を治療戦略の策定に フィードバックすること, それらのプロセスを経て, 形態のみならず機能の指標も含めた因子を組み込んだ新た な治療戦略を策定すること, となるであろうか.

会員と読者諸兄によるさらなる知見の集積を切に期待する.

\section{【参考文献】}

1) 石丸和彦, 上野高義, 井手春樹, ほか: 純型肺動脈閉鎖術後遠隔期における心臟MRI検査を用いた両心室収縮機能評価. 日 小児循環器会誌 2013；29：118-124

2) 近藤千里, 池田亜希: 2. 成人先天性心疾患の画像診断: 最近のトピック. Annual Review 循環器 2012, 東京, 中外医学社, 2012, 218-223

3) Fritz J, Solaiyappan M, Tandri H, et al: Right ventricle shape and contraction patterns and relation to magnetic resonance imaging findings. J Comput Assist Tomogr 2005; 29: 725-733 
4) Hendel RC, Patel MR, Kramer CM, et al: ACCF/ACR/SCCT/SCMR/ASNC/NASCI/SCAI/SIR 2006 appropriateness criteria for cardiac computed tomography and cardiac magnetic resonance imaging: a report of the American College of Cardiology, Foundation/American College of Radiology, Society of Cardiovascular Computed Tomography, Society for Cardiovascular Magnetic Resonance, American Society of Nuclear Cardiology, North American Society for Cardiac Imaging, Society for Cardiovascular Angiography and Interventions, and Society of Interventional Radiology. J Am Coll Cardiol 2006; 48: 1475-1497

5) Sugeng L, Mor-Avi V, Weinert L, et al: Quantitative assessment of left ventricular size and function: side-by-side comparison of real-time three-dimensional echocardiography and computed tomography with magnetic resonance reference. Circulation $2006 ; 114$ : 654-661

6) 佐久間肇：心臓MRIの進歩. J Cardiol Jpn Ed 2011；6：269-273

7) 武村 濃: 小児心臓MRIの有用性. 日放線技会誌 2007；63：689-696

8) Suga H, Sagawa K, Shoukas AA: Load independence of the instantaneous pressure-volume ratio of the canine left ventricle and effects of epinephrine and heart rate on the ratio. Circ Res $1973 ; \mathbf{3 2}: 314-322$

9) Suga H, Sagawa K: Instantaneous pressure-volume relationships and their ratio in the excised, supported canine left ventricle. Circ Res $1974 ; 35: 117-126$

10) Segers P, Tchana-Sato V, Leather HA, et al: Determinants of left ventricular preload-adjusted maximal power. Am J Physiol Heart Circ Physiol 2003；284：H2295-H2301

11) Kass DA, Beyar R: Evaluation of contractile state by maximal ventricular power divided by the square of end-diastolic volume. Circulation 1991; 84:1698-1708

12) Takagaki M, McCarthy PM, Chung M, et al: Preload-adjusted maximal power: a novel index of left ventricular contractility in atrial fibrillation. Heart $2002 ; 88: 170-176$

13) Zhong L, Tan RS, Ghista DN, et al: Validation of a novel noninvasive cardiac index of left ventricular contractility in patients. Am J Physiol Heart Circ Physiol 2007; 292: H2764-H2772

14) Schenk S, Popović ZB, Ochiai Y, et al: Preload-adjusted right ventricular maximal power: concept and validation. Am J Physiol Heart Circ Physiol 2004; 287: H1632-H1640

15) Leather HA, Segers P, Sun YY, et al: The limitations of preload-adjusted maximal power as an index of right ventricular Contractility. Anesth Analg 2002; 95: 798-804

16) Segers $P$, Leather HA, Verdonck $P$, et al: Preload-adjusted maximal power of right ventricle: contribution of end-systolic P-V relation intercept. Am J Physiol Heart Circ Physiol 2002; 283: H1681-H1687

17) 山岸正明：II. 外科 純型肺動脈閉鎖の外科治療. 日小児循環器会誌 $2011 ； 27$ :69-75

18) 矢崎 諭：I. 内科 純型肺動脈閉鎖の診断と内科的管理. 日小巟循環器会誌 $2011 ; 27 ： 62-68$

19) Ashburn DA, Blackstone EH, Wells WJ, et al: Determinants of mortality and type of repair in neonates with pulmonary atresia and intact ventricular septum. J Thorac Cardiovasc Surg 2004; 127: 1000-1008

20) Liava'a M, Brooks P, Konstantinov I, et al: Changing trends in the management of pulmonary atresia with intact ventricular septum: the Melbourne experience. Eur J Cardiothorac Surg 2011; 40: 1406-1411

21) John AS, Warnes CA: Clinical outcomes of adult survivors of pulmonary atresia with intact ventricular septum. Int J Cardiol 2012; $161: 13-17$

22) Hoashi T, Kagisaki K, Kitano M, et al: Late clinical features of patients with pulmonary atresia or critical pulmonary stenosis with intact ventricular septum after biventricular repair. Ann Thorac Surg 2012; 94:833-841

23) Mishima A, Asano M, Sasaki S, et al: Long-term outcome for right heart function after biventricular repair of pulmonary atresia and intact ventricular septum. Jpn J Thorac Cardiovasc Surg 2000; 48: 145-152

24) Romeih S, Groenink M, van der Plas MN, et al: Effect of age on exercise capacity and cardiac reserve in patients with pulmonary atresia with intact ventricular septum after biventricular repair. Eur J Cardiothorac Surg 2012; 42: 50-55

25) Yoshimura N, Yamaguchi M: Surgical strategy for pulmonary atresia with intact ventricular septum: initial management and definitive surgery. Gen Thorac Cardiovasc Surg 2009; 57:338-346

26) Babu-Narayan SV, Kilner PJ, Li W, et al: Ventricular fibrosis suggested by cardiovascular magnetic resonance in adults with repaired tetralogy of fallot and its relationship to adverse markers of clinical outcome. Circulation 2006; 113: 405-413

27) Rathod RH, Prakash A, Powell AJ, et al: Myocardial fibrosis identified by cardiac magnetic resonance late gadolinium enhancement is associated with adverse ventricular mechanics and ventricular tachycardia late after fontan operation. J Am Coll Cardiol 2010; 55: 1721-1728

28) LiangXC, Lam WW, Cheung EW, et al: Restrictive right ventricular physiology and right ventricular fibrosis as assessed by cardiac magnetic resonance and exercise capacity after biventricular repair of pulmonary atresia and intact ventricular septum. Clin Cardiol $2010 ; 33$ : 104-110 